Chirurgia (2019) 114: 494-501

No. 4, July - August

Copyright@ Celsius

http://dx.doi.org/10.21614/chirurgia.114.4.494

\title{
Osteomyelitis in Paediatric Patients: Epidemiology, Pathogenesis and Management of 94 Cases
}

\author{
Bogdan Popescu, Iulia Tevanov, Madalina Carp, Alexandru Ulici
}

Department of Pediatric Orthopedic Surgery, Emergency Hospital for Children “Grigore Alexandrescu”, Bucharest, Romania

Corresponding author:

Alexandru Ulici, MD

President of the Romanian Pediatric Orthopedic Society, Chief of Surgery,

Department of Pediatric Orthopedic

Surgery, Emergency Hospital for Children

"Grigore Alexandrescu"

Associate Professor at Carol Davila

University of Medicine and Pharmacy,

Bucharest, Romania

30-32, lancu de Hunedoara Bvd, 011733

E-mail: alexandruulici@yahoo.com

\section{Abbreviations:}

$\mathrm{AHO}$ - acute hematogenous

osteomyelitis

WBC - white blood cells

ESR - erithricyte sedimentation rate

CRP $-C$ reactive protein

$\mathrm{SD}-$ standard deviation

$\mathrm{F}$ - female

$\mathrm{M}$ - male

CT - computerized tomography

$\mathrm{MRI}$ - magnetic resonance imaging
Received: 08.02.2018

Accepted: 11.04 .2018

\section{Rezumat}

Osteomielita la pacientii pediatrici: epidemiologie, patogeneză si managementul a 94 de cazuri

Introducere: Osteomielita acutã hematogenã are o incidențã în scãdere în țãrile dezvoltate. Aceastã afecțiune poate duce la o distrugere rapida a structurii osoase. Întârzierea diagnosticului poate avea consecințe nefaste precum impotența funcționalã sau chiar deces.

Obiectivul acestui studiu este de a identifica principalii factori ce pot duce la un prognostic negativ şi de a stabili profilul pacientului ce suferã de osteomielita acutã hematogenã care are un prognostic rezervat.

Metode: Am efectuat un studiu retrospectiv unicentric, în care am evaluat datele medicale a 94 de pacienți diagnosticați cu osteomielita acutã hematogenã, într-un interval de timp de 10 ani. Am analizat istoricul medical complet al pacientului, incluzând: vârsta în momentul diagnosticãrii, sexul, statusul socioeconomic, simptome, poarta de intrare, agentul patogen, localizarea infecției, imagini radiologice, tratamentul şi prognosticul. Am observat faptul cã pacienții de sex masculin cu proveniențã din mediul rural, sunt predispuşi unui prognostic nefavorabil, probabil, datoritã faptului cã aceştia sunt mai expuşi la traumatisme, iar in mediul rural adresabilitatea la serviciile medicale este limitatã. Cel mai frecvent întâlnit agent patogen a fost Stafilococul auriu (84 cazuri). Tratamentul osteomielitei acute hematogene este unul complex şi de lungã duratã şi constã în antibiotico-terapie ghidatã de antibiogramã şi incizii chirurgicale de drenaj, debridarea țesuturilor afectate. 
Rezultate: Evoluția bolii a fost spre cronicizare în majoritatea cazurilor diagnosticate tardiv. Cele mai frecvente complicații au fost sepsisul şi fracturile pe os patologic. Pacienții cu prognostic negativ au fost caracterizați de vârsta micã la debutul bolii, culturi negative repetate, tratament chirurgical aplicat tardiv, proveniența din mediul rural şi sex masculin.

Cuvinte cheie: osteomielita acuta hematogena, ortopedie pediatrica, infecții osoase

\section{Abstract}

Background: Acute hematogenous osteomyelitis (AHO) has a currently declining incidence in developed countries. It can cause rapid destruction that can lead to functional impairment or even death if misdiagnosed and not treated urgently. The objective of this study is to identify the main factors that may lead to a poor outcome and to establish a profile of the patient suffering from AHO that might have a negative outcome.

Methods: A retrospective single centre study was conducted, evaluating data from the medical records of 94 patients that suffered from AHO, in a 10 years interval. Complete medical history including age at diagnosis, sex, socioeconomic status, symptoms, entry site, pathogen agent, location of infection, radiological features, treatment and outcome were recorded. A male predominance was observed and boys from rural area are more prone to have a bad outcome, because of the fact that boys are more exposed to trauma, and, in rural areas, they do not benefit from a proper access to emergency medical care. Staphylococcus aureus was the most common bacteria, testing positive in 84 cases. The treatment of AHO is long lasting and complex. It consists of appropriate antimicrobial therapy and may require surgical incision and drainage, debridement for removal of all infective and necrotic material.

Results: Disease evolution was towards chronicity in the cases that were diagnosed late. The most frequent complications were sepsis and pathological fractures. Patients that had a negative outcome were characterized by young age, repeated negative cultures, delayed surgery, rural provenience and masculine sex.

Key words: acute hematogenous osteomyelitis, pediatric orthopedics, bone infection

\section{Introduction}

Acute osteomyelitis is the infection of the bone and marrow caused by bacteria. Worldwide incidence ranges between $1 / 1000$ to $1 / 20000$, fifty percent occurring in children younger than 5 years of age $(1,2,3)$. A study conducted in Glasgow, Scotland, showed an incidence decline of 44\% from 1970 to 1990 and a 50\% decline between 1990 and 1997. The study was carried on a population of children younger than 13 years of age $(4,5)$. Pediatric acute hematogenous osteomyelitis (AHO) incidence is continuously decreasing in developed countries as Street et al (2015) showed in a 10-year retrospective study performed in 2 hospitals from New Zealand, the incidence being of 1 in 4000 cases, with a male predominance (6).

The most common pathogen is Staphylococcus aureus, being present in 70 to $90 \%$ of AHO infections in children. Other pathogens that are responsible for AHO are streptococci, Staphylococcus epidermidis, enterococci, E Coli, B hhemolytic streptococci, Haemophilus influenzae, anaerobes and fungi $(7,8,9)$.

Bacterial dissemination can be hematogenous, contiguous (infection originating from soft tissues that spreads to the bone) or direct inoculation (open fractures, puncture wounds, prostheses) (10). Risk factors include trauma, sepsis, bacteremia, chronic catheterization or 
vascular lines, immunodeficiency (11).

AHO most frequently affects the metaphyseal region of long bones (27\% femur, $22 \%$ tibia, $5 \%$ fibula, $12 \%$ humerus, $4 \%$ radius, $3 \%$ ulna) (12, 13). The rich metaphyseal blood supply, with vascular loops and turbulent flow, facilitate bacterial colonization $(14,15)$. Bacterial exponential growth leads to bone resorption. A purulent exudate is formed and may exit the metaphyseal cortex, creating a sub periosteal abscess $(9,16)$.

Acute osteomyelitis must be considered whenever a child suffers from fever and localized bone pain. The localisation of pain can lead to difficult diagnosis, as it might be reported as abdominal or back pain. Local examination reveals erythema, swelling, warmth or other skin changes. These signs of inflammation may appear when the infection has progressed through the metaphyseal cortex into the sub periosteal space $(17,18)$.

The treatment of AHO is long lasting and complex. It consists of appropriate antimicrobial therapy and may require surgical incision and drainage, debridement for removal of all infective and necrotic material (17). Cast immobilization can be used in order to reduce muscular activity, dissemination, inflammation, decrease pain and prevent complications.

The objective of this study is to identify the main factors that may lead to a poor outcome and to establish a profile of the patient suffering from AHO that mighthave a negative outcome.

\section{Methods}

A retrospective single centre study was conducted, evaluating data from the medical records of 94 patients that suffered from AHO, in a 10 years interval (2006-2016). The study was approved by the Ethics Board in our institution.

The patients included in our study were children suffering from AHO; exclusion criteria were open fractures or bone surgery at the site of infection, nosocomial infections, presence of prosthetic materials.
Complete medical history including age at diagnosis, sex, socioeconomic status, symptoms, entry site, pathogen agent, location of infection, radiological features, treatment and outcome were recorded from the clinical notes.

The AHO diagnosis was established based on the clinical examination findings, laboratory tests and imagistic investigations. Clinical examination revealed general and local symptoms such as the swelling extent, erythema, antalgic posture, gait changes, the site of maximum pain and functional impairment. Laboratory tests consisted in white and red blood cells count (WBC $>12000$ cells $/ \mathrm{mL}$ ), erythrocyte sedimentation rate $(\mathrm{ESR}>40$ $\mathrm{mm} / \mathrm{h}$ ), C Reactive Protein (CRP >10,5 $\mathrm{mg} / \mathrm{dL}$ ), urinalysis, blood cultures, pus cultures. The latter two were obtained, when possible, before the administration of antibiotics. Imagistic investigations were based on plain X-rays that were closely inspected for lytic or sclerotic lesions of the bone, osteopenia, periosteal elevation or calcification, cortical disruptions, joint effusions and the aspect of the surrounding soft tissues. Ultrasonography of the affected area was performed to reveal a potential sub periosteal abscess.

The medical treatment consisted of antibiotics, supportive care, casting and surgical intervention by means of incision, evacuation of the sub periosteal abscess and drainage of the pus, drilling holes in the affected bone and antiseptic lavage.

Resolution of osteomyelitis with positive outcome was based on improvement in clinical signs, decrease of inflammatory markers and no relapse. Cronicisation, death, chronic multifocal and chronic arthritis were considered as negative outcome.

The statistical data was processed with Microsoft Excel and www.medcalc.org. Non parametrical Chi Square Test was used to compare variables.

In the univariate analyses we included the following variables: age, sex, socioeconomically status, site of infection, infectious pathogens, entrance sitefor the pathogens, signs and symptoms at admission. 


\section{Results}

Case distribution by age (0-18 years with a median age of 11) showed a high incidence in the 11-13 year olds, and 11 cases were encountered in the 0-2 year olds. A male predominance was observed, $52(55 \%)$ boys vs. $42(45 \%)$ girls, male to female ratio 1.23 . The rural/urban patient distribution was $56 / 38$ and $53,5 \%$ of the rural patients had negative outcome.

Concerning the site of infection, the femur (35 patients $-37,2 \%$ ) and the tibia (30 patients - $32 \%$ ) were the most affected bones, followed by the humerus, forearm bones and fibula. Ten patients $(10,6 \%)$ suffered from multifocal osteomyelitis.

The entrance site was suspected to be cutaneous in most cases $(74,4 \%)$, in 16 patients the site was pulmonary or otorhinolaryngology related and in 8 cases the entrance site couldn't be established (Table 1).

The major symptoms were: pain (94 cases), functional impairment (72 cases), swelling (60 cases) and general signs. General symptoms were those of severe infection (fever, shivering, pallor, increased heart rate), gastrointestinal (nausea, vomiting) and urinary tract related (oliguria) (Table 2).

Local examination revealed pain of variable intensity in all patients, antalgic posture (90 cases), erythema (84 cases), increased local warmth (82 cases), partial functional impairment (73 sites) and complete functional impairment (42 sites) (Table 2).

Most patients presented with anemia $(<10 \mathrm{~g} / \mathrm{l})$, leukocytosis $(>15000 / \mathrm{mm} 3)$ and an ESR value of over $100 \mathrm{~mm} / \mathrm{h}$. In 36 patients the hemocultures were positive. Cultures from pus specimens were done and antibiotic sensitivity tests were performed. The most common pathogen was Staphylococcus aureus (89\%), followed by Hemolytic streptococcus (8,5\%).

The radiological examination revealed:

Table 1. Epidemiological and clinical data vs. outcome

\begin{tabular}{|c|c|c|c|}
\hline & $\begin{array}{c}\text { Positive outcome } \\
-58,61.7 \%\end{array}$ & $\begin{array}{c}\text { Negative outcome } \\
\text { (cronicisation, multifocal, } \\
\text { arthritis and death) - } 36,38.3 \%\end{array}$ & $P^{*}$ \\
\hline$\overline{\mathrm{AGE}}$ & & & \\
\hline Median Years (SD)-11 (4.7) & $11.5,(4.019)$ & $9,(5.177)$ & 2 \\
\hline $\begin{array}{l}\text { GENDER } \\
\text { F- } 42(45 \%) \\
\text { M- } 52(55 \%)\end{array}$ & $\begin{array}{l}31(25.91)(1.00) \\
2732.09)(0.81)\end{array}$ & $\begin{array}{ll}11(16.09) & (1.61) \\
25(19.91) & (1.30)\end{array}$ & 0.03 \\
\hline $\begin{array}{l}\text { GEOGRAPHIC AREAS } \\
\text { Rural } 56 \\
\text { Urban } 38\end{array}$ & $\begin{array}{cc}26 & (34.55) \\
32(23.12) \\
32.45) & (3.12)\end{array}$ & $\begin{array}{c}30(21.45)(3.41( \\
6(14.55)(5.03)\end{array}$ & 0.0002 \\
\hline $\begin{array}{l}\text { THE ENTRANCE SITE } \\
\text { Cutaneous- } 70 \\
\text { Pulmonary or ORL-16 } \\
\text { Not established-8 }\end{array}$ & $\begin{array}{c}47(43.19)(0.34) \\
6(9.87)(1.52) \\
5(4.94)(1.52)\end{array}$ & $\begin{array}{c}23(26.81)(0.54) \\
10(6.13)(2.45) \\
3(3.06)(0.00)\end{array}$ & 88 \\
\hline $\begin{array}{l}\text { PATHOGEN AGENT } \\
\text { Staphylococcus aureus -84(89\%) } \\
\text { Hemolytic streptococcus-8(8,5\%) } \\
\text { Other pathogen-2(2,5\%) }\end{array}$ & $\begin{array}{c}55(52.96)(0.08) \\
3(5.04)(0.08 \\
0\end{array}$ & $\begin{array}{c}29(31.04)(0.13) \\
5(2.96)(1.41) \\
2\end{array}$ & 0.11 \\
\hline $\begin{array}{l}\text { LOCATION OF THE INFECTIOS PROCES } \\
\text { Lower limb long bones } \\
\text { Upper limb long bones } \\
\text { Other** } \\
\text { Multifocal }\end{array}$ & $\begin{array}{c}46(44.88)(0.03) \\
10(8.98)(0.12) \\
2(4.14)(1.11) \\
0\end{array}$ & $\begin{array}{c}19(20.12)(0.06) \\
3(4.02)(0.26) \\
4(1.86)(2.47) \\
10\end{array}$ & 132 \\
\hline
\end{tabular}


Table 2. Diagnosis Approach

\begin{tabular}{|c|c|c|c|}
\hline Diagnostic Approach & Number & Sensitivity & Comment \\
\hline \multicolumn{4}{|l|}{ Clinical Manifestation } \\
\hline Local Pain & 94 & $100 \%$ & \\
\hline Position of relief & 90 & & $\begin{array}{l}\text { Most frequent was encountered in lower limbs, } \\
\text { especially in osteomyelitis of the femur, the thigh } \\
\text { being in abduction and internal rotation }\end{array}$ \\
\hline Erythema & 84 & $95 \%$ & \\
\hline Local warmth & 82 & $87 \%$ & \\
\hline Swelling & 60 & $63 \%$ & \\
\hline Complete functional impairment & 42 & $44 \%$ & In the cases with pathological fractures \\
\hline General Symptoms & 48 & $51 \%$ & $\begin{array}{l}\text { General signs were of severe infection (fever, } \\
\text { shivering, pallor, increased heart rate), gastro- } \\
\text { intestinal (nausea, vomiting) and urinary tract } \\
\text { related (oliguria). }\end{array}$ \\
\hline \multicolumn{4}{|l|}{ Radiological features } \\
\hline Lytic lesions & 82 & $87 \%$ & \\
\hline Cortical doubling & 64 & $68 \%$ & $\begin{array}{l}\text { Cortical doubling, the expression of periosteum } \\
\text { elevation became visible after } 3 \text { weeks from onset }\end{array}$ \\
\hline Soft tissue edema & 30 & $31 \%$ & $\begin{array}{l}\text { Initially the only modification was discrete soft } \\
\text { tissue edema }\end{array}$ \\
\hline
\end{tabular}

double cortical line sign, periosteum elevation, which became visible after 3 weeks from onset (Fig. 1). The earliest changes consisted of soft tissue edema (Table 2).

Casting and antibiotic treatment were performed in all 94 patients. In 65 patients, ultra-

Figure 1. Radiograph of the femur in a lateral view showing a double cortical line sign sonography revealed sub periosteal abscess and surgical intervention was performed (Fig. 2).

After applying the treatment, no sequelae healing was achieved in 58 patients $(61,7 \%)$, while 27 patients $(28,7 \%)$ had a poor outcome that led to chronic infection. From the 0-2 years old group, one patient died because of sepsis.

The most frequent late complication was severe sepsis (12 cases) followed by septic metastasis (10 cases), pathological fracture (9 cases), septic arthritis (8 cases) and pathological dislocation (1 case). Pathological fractures were mainly encountered in lower limbs, mostly affecting the tibia, but they also occurred in rare sites, like the clavicle, as seen in Fig. 3.

\section{Discussion}

Case distribution by age showed a high incidence in the 11-13 year olds, overlapping with the maximum skeletal growth period and an abundant metaphyseal blood flow (19). Eleven cases were encountered in the 0-2 year olds. Unfortunately, the majority of the patients in 


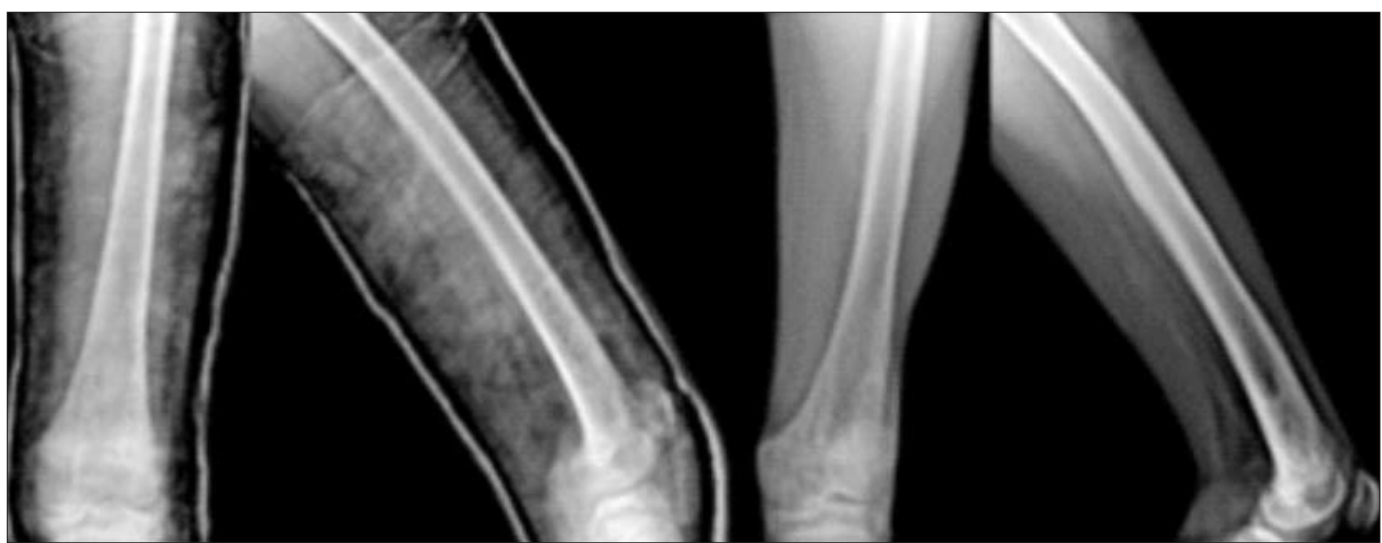

Figure 2. Radiograph of the femoral osteomyelitic site, in AP and lateral view. A. 6 weeks post surgery we can see the double cortical line sign and drilling sites. B. The aspect of the affected femur, 5 months after surgery

this age group had negative outcome, because of the loss of their maternal immunity and subtle symptoms at this age, that led to latediagnosis (13). Also, in infants, because of the continuity of circulation across the physis until 18 months of age, the pathogen agent can reach the epiphysis and the joint, causing permanent epiphyseal damage and joint infection (20).

Concerning case distribution by sex, a male predominance was observed. This can be explained by the higher exposure to trauma in boys (21). The rural/urban distribution was comparable (26/32) in cases that had good outcomes, but we noted a significant difference $(30 / 6)$ in patients with negative outcome $(p=0.002)$ (Table 1). In our country, boys from rural areas are more involved in activities that are prone to trauma and injuries, and they do not benefit from a proper access to emergency medical care. The negative outcome is related

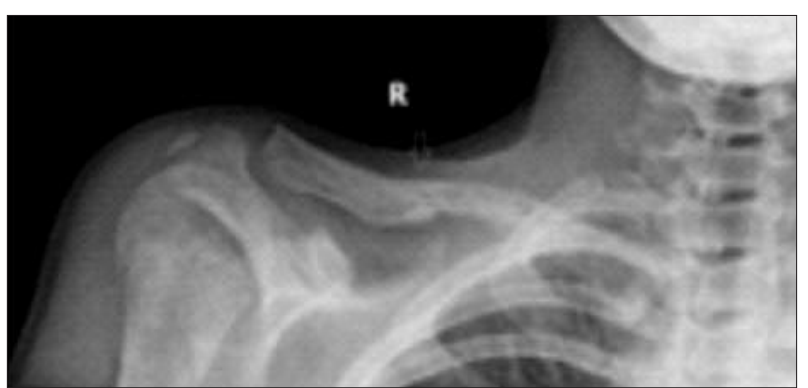

Figure 3. Radiograph showing a pathological fracture of the clavicle as a late complication of osteomyelitis to the fact that these patients are latediagnosed and treated.

The most frequent site of infection was the metaphysis of the long bones which is consistent with literature data (22). The femur and tibia were the most affected bones, followed by the humerus, forearm bones and fibula; rare sites such as calcaneus, pelvis or scapula were also affected. Ten patients had more than one site of infection. The site of infection didn't influence the evolution of the disease nor the outcome, but all ten patients with multifocal osteomyelitis had a poor outcome, as seen in Table 1. Hematogenous multifocal osteomyelitis in children is a rare and dangerous form of osteomyelitis in which sepsis can develop quickly and need rapid treatment (23).

Most patientsreported pain, swelling and partial or total functional impairment. These symptoms were associated with general signs of severe infection like shivering and septic fever. General condition impairment with circulatory (pallor, cyanosis, cold and sweaty extremities), urinary (oliguria) and digestive disorders have been reported. The intensity of general phenomena was in direct relation with the patient's age, infants presenting with less noisy and often nonspecific symptoms.

Clinical examination revealed swelling, erythema, clinically apparent venous circulation, antalgic posture of the affected limb, increased local warmth, pain at manipulation with 
maximum intensity in the metaphyseal areas, limited active range of motion; except for the cases which had articular involvement, the passive joint motion was relatively unaffected. Pain is the most common symptom in patients with bone or joint infection, but is frequently absent in small children. Rather than expressing pain, children limp, refuse to walk, to bear weight or move a limb (9).

Usually, the child with AHO has high fever, $>380 \mathrm{C}$ in $36 \%$ to $74 \%$ of patients $(7,24,25)$. In our study the major symptoms were: pain, functional impairment, swelling and general signs. General symptoms were those of severe infection (fever, shivering, pallor, increased heart rate), gastrointestinal (nausea, vomiting) and urinary tract related (oliguria) (Table 2).

Standard X-ray shows bone changes when osteomyelitis is already established and appears as a lytic metaphyseal lesion with periosteal elevation and new bone formation.

Ultrasonography is a good method for identifying sub periosteal abscess in acute osteomyelitis. This procedure was proven to be helpful in the diagnose of AHO in small children with insidious symptoms and could establish the indication for surgical treatment (23). For the patients in our study, that we considered to be lately diagnosed, an ultrasonographically identified abscess at hospital admission.

CT helps determine the destruction of bone and soft tissue. MRI can be used to differentiate osteomyelitis from cellulitis and identify abscesses $(9,12)$. In our patients, radiologic examination revealed AHO characteristic findings. The earliest changes were discreet with soft tissue edema (Table 2). First lytic lesions appeared on x-rays after 14 days, conventional imaging having a sensitivity of $20-75 \%$ and a specificity of $75-83 \%$, with limited level of evidence (II-III) $(26,27)$.

Most patients presented with anemia $(<10 \mathrm{~g} / \mathrm{l})$, leukocytosis $\left(>15000 / \mathrm{mm}^{3}\right)$ and an ESR value of over $100 \mathrm{~mm} / \mathrm{h}$. This value had a great predictive value in establishing the diagnosis, as Riise et al (2008) showed in their study that an ESR of more than $40 \mathrm{~mm} / \mathrm{h}$ has the highest predictive value (26\%) (1).

Staphylococcus aureus is one of the most common causes of bacteremia, with a high mortality rate of $65-70 \%$ in the pre-antibiotic era, and currently $20-40 \%$ mortality in 30 days, despite adequate treatment $(28,29)$. Human skin is optimized to prevent the entrance and the colonisation of Staphylococcus aureus, the most common species of staphylococcus that can be found on the individuals skin. However, Staphylococcus aureus infections occur in skin impaired by diseases or wounds (30).

In our study the most common etiological pathogen was Staphylococcus aureus (89\%), followed by Hemolytic streptococcus $(8,5 \%)$.

Osteomyelitis therapeutic approach is a complex association of drug therapy, orthopedic and surgical treatment (13). Considering the fact that the main pathogen incriminated for AHO was Staphylococus aureus, the initial drug therapy consisted in intravenous administration of an association of empiric antistaphylococcus antibiotics, mainly Oxacillin and Gentamicin. In some cases Cephalosporin were used. Antibiotic treatment was administered parenterally until the normalization of CRP levels, and then switched to oral administration of Oxacillin or Erythromycin. Alongside with antibiotic therapy, vitamins, blood transfusions and immunity stimulators were administered.

After the treatment, healing with no sequelae was achieved in 58 patients $(61,7 \%)$, while 27 patients $(28,7 \%)$ had a poor outcome that led to chronic infection. The vast majority of the chronic patients presented late with a developed abscess. From the 0-2 years old group, one patient died because of sepsis. This patient had a late-diagnosed acute osteomyelitis, being admitted in the hospital when the disease had advanced in the stage of abscess formation (31).

The limitation of our study is its retrospective nature and the lack of a long-term follow-up in most of the patients. The lack of useful data concerning the debut of symptoms associated with hospital presentation also constitutes a drawback. 


\section{Conclusions}

AHO has a high incidence in the 11-13 years old overlapping the period of maximal osseous growth. The 0-2 year olds had a negative outcome because of the loss of their maternal immunity and subtle symptoms at this age, that leads to late-diagnosis. A male predominance was observed and boys from rural area are more prone to have a bad outcome, because boys are more exposed to trauma, and, in rural areas, they do not benefit from a proper access to emergency medical care.

The single site form was the most frequent, with a predilection for long bones especially the femur and tibia. The entrance site was, for the majority of patients, cutaneous and the most common etiological pathogen was Staphylococcus aureus.

Disease evolution was towards chronicity in the cases where the diagnosis was established late. The most frequent complications were sepsis and pathological fractures. Patients that had a negative outcome were characterized by young age, repeated negative cultures delayed surgery, rural provenience and masculine sex.

\section{Conflict of interests: none declared.}

\section{References}

1. Riise $\emptyset R$, Kirkhus E, Handeland KS, Flatø B, Reiseter T, Cvancarova $M$, et al. Childhood osteomyelitis-incidence and differentiation from other acute onset musculoskeletal features in a population-based study. BMC Pediatr. 2008 Oct 20;8:45.

2. Krogstad P. Smigh AL. Osteomyelitis and septic arthritis. In: Feigin RD, Cherry JD, eds. Textbook of pediatric infectious disease. Philadelphia, PA: WB Saunders, 1998:683-704.

3. Gutierrez KM. Osteomyelitis. In: Iong SS, Pickering LK, Prober CG, eds. Principles and practice of pediatric infectious disease. New York, NY: Churchill Livingstone, 1997:528-536.

4. Blyth MJ, Kincaid R, Craigen MA, Bennet GC. The changing epidemiology of acute and subacute haematogenous osteomyelitis in children. J Bone Joint Surg Br. 2001:83(1):99-102.

5. Craigen MAC, Watters J, Hackett JS. The changing epidemiology of osteomyelitis in children. J Bone Joint Surg (Br). 1992;74-B:541- 5.

6. Street M, Puna R, Huang M, Crawford H. Pediatric Acute Hematogenous Osteomyelitis. J Pediatr Orthop. 2015;35(6):634-9

7. Wang CL, Wang SM, Yang YJ, Tsai CH, Liu CC. Septic arthritis in children: relationship of causative: pathogens, complications and outcomes. J Microbiol Immunol Infect. 2003:36(1):41-6.

8. Petola H, Kallio MJ, Unkila-Kallio L. Reduced incidence of septic arthritis in children by Haemophilus influenza type-b vaccination: implications for treatment. J Bone Joint Surg Br. 1998;80(3):4713.

9. Weinstein SL, Flynn JM. Lovell and Winter's Pediatric Orthopedics; 7th edition; Ed Wolters Kluwer 2013; $p$ 369-386.

10. Calhoun JH, Manring MM. Adult osteomyelitis. Infect Dis Clin North Am. 2005;19(4):765-86.

11. van Schuppen J, van Doorn MM, van Rijn RR. Childhood osteomyelitis: imaging characteristics. Insights Imaging. 2012;3(5):519-33.

12. Song KM, Sloboda JF. Acute hematogenous osteomyelitis in children. J Am Acad Orthop Surg. 2001;9(3):166-75.

13. Herring JA et al: Tachdjian's Pediatric Orthopaedics 5th edition; Ed Elsevier 2014; p 1042-1054

14. Hobo T. Zur pathogencse de akuten haematogenen osteomyelitis, mit berucksichtigungder vitalfarbungs leher. Acta Scolar Met Kicto 1921;4:1-2.

15. Lee YJ, Sadigh S, Mankad K, Kapse N, Rajeswaran G. The imaging of osteomyelitis; Quant Imaging Med Surg. 2016 Apr:6(2):184-98.

16. Jaramillo D. Infection: musculoskeletal. Pediatr Radiol. 2011;41 Suppl 1:S127-34.

17. Harik NS, Smeltzer MS. Management of acute hematogenous osteomyelitis in children. Expert Rev Anti Infect Ther. 2010;8(2): 175-81.

18. Krogstad P. Osteomyelitis. In: Feigin RD, Cherry JD, DemmlerHarrison GD, Kaplan SL, editors. Textbook of Pediatric Infectious Diseases. 6th Edition. PA, USA: Saunders Elsevier; 2009. pp. 725-742.

19. Rauch F. The dynamics of bone structure development during pubertal growth. J Musculoskelet Neuronal Interact. 2012;12(1):1-6.

20. Trueta J. The three types of acute haematogenous osteomyelitis. Bone \& Joint Journal. 1959;41-B(4):671-680.

21. Chiappini E, Camposampiero C, Lazzeri S, Indolfi G, De Martino M, Galli L. Epidemiology and Management of Acute Haematogenous Osteomyelitis in a Tertiary Paediatric Center. Tchounwou PB, ed. Int J Environ Res Public Health. 2017;14(5). pii: E477.

22. Sinikumpu JJ, Tapiainen T, Korhonen J, Perhomaa M, Serlo W. Acute hematogenous osteomyelitis in children. Duodecim. 2014;130(16):1591-8. Finnish

23. Sreenivas T, Nataraj AR, Menon J, Patro DK. Acute multifocal haematogenous osteomyelitis in children. J Child Orthop. 2011; 5(3):231-5. Epub 2011 May 12.

24. Scott RJ, Christofersen MR, Robertson WW Jr, Davidson RS, Rankin L, Drummond DS. Acute osteomyelitis in children: a review of 116 cases. J Pediatr Orthop. 1990:10(5):649-52.

25. Klein DM, Barbera C, Gray ST, Spero CR, Perrier G, Teicher JL. Sensitivity of objective parameters in the diagnosis of pediatric septic hips. Clin Orthop Relat Res. 1997;(338):153-9.

26. Kao HC, Huang YC, Chiu CH, Chang LY, Lee ZL, Chung PW, et al. Acute hematogenous osteomyelitis and septic arthritis in children. J Microbiol Immunol Infect. 2003;36(4):260-5.

27. Jaramillo D. Infection: musculoskeletal. Pediatr Radiol. 2011; 41(Suppl 1):S127-S134. doi: 10.1007/s00247-011-2001-y

28. MacNeal WJ, Frisbee FC, McRae MA. Staphylococcemia 19311940. Five hundred patients. Am J Clin Pathol. 1942;12:6.

29. Melzer M, Welch C. Thirty-day mortality in UK patients with community-onset and hospital-acquired meticillin-susceptible Staphylococcus aureus bacteraemia. J Hosp Infect. 2013; 84(2): $143-50$

30. Choi JH, Seo HS, Lim SY, Park K. Cutaneous Immune Defenses Against Staphylococcus aureus Infections J Lifestyle Med. 2014; 4(1): $39-46$

31. Cole W, Dalziel R, \& Leitl S. Treatment of acute osteomyelitis in childhood. Bone \& Joint Journal. (1982;64-B(2):218-223. 